\title{
Control of downy brome (Bromus tectorum) and Japanese brome (Bromus japonicus) using glyphosate and four graminicides: effects of herbicide rate, plant size, species, and accession
}

\section{Authors: Emily P. Metier, Erik A. Lehnhoff, Jane Mangold, Matthew J. Rinella, and Lisa J. Rew}

(C) This manuscript version is made available under the CC-BY-NC-ND 4.0 license. Originally published at 10.1017/wet.2019.112.

Metier, Emily P., Erik A. Lehnhoff, Jane Mangold, Matthew J. Rinella, and Lisa J. Rew. "Control of Downy Brome (Bromus Tectorum) and Japanese Brome (Bromus Japonicus) Using Glyphosate and Four Graminicides: Effects of Herbicide Rate, Plant Size, Species, and Accession." Weed Technology 34, no. 2 (November 5, 2019): 284-291. doi:10.1017/ wet.2019.112. 


\title{
Control of downy brome (Bromus tectorum) and Japanese brome (Bromus japonicus) using glyphosate and four graminicides: effects of herbicide rate, plant sıze, species, and accession
}

\author{
Emily P. Metier ${ }^{1}$, Erik A. Lehnhoff ${ }^{2}$, Jane Mangold ${ }^{3}$, Matthew J. Rinella ${ }^{4}$ and Lisa J. Rew ${ }^{5}$

\begin{abstract}
${ }^{1}$ Graduate Research Assistant, Department of Land Resources and Environmental Science, Montana State University, Bozeman, MT, USA; ${ }^{2}$ Assistant Professor, Department of Entomology, Plant Pathology and Weed Science, New Mexico State University, Las Cruces, NM, USA; ${ }^{3}$ Associate Professor, Department of Land Resources and Environmental Science, Montana State University, Bozeman, MT, USA; ${ }^{4}$ Range Management Specialist, USDA-ARS Fort Keogh LARRL, Miles City, MT, USA and ${ }^{5}$ Professor, Department of Land Resources and Environmental Science, Montana State University, Bozeman, MT, USA
\end{abstract}

\begin{abstract}
Nonnative annual brome invasion is a major problem in many ecosystems throughout the semiarid Intermountain West, decreasing production and biodiversity. Herbicides are the most widely used control technique but can have negative effects on co-occurring species. Graminicides, or grass-specific herbicides, may be able to control annual bromes without harming forbs and shrubs in restoration settings, but limited studies have addressed this potential. This study focused on evaluating the efficacy of glyphosate and four grami-nicides to control annual bromes, specifically downy brome and Japanese brome. In a green-house, glyphosate and four graminicides (clethodim, sethoxydim, fluazifop-P-butyl, and quizalofop-P-ethyl) were applied at two rates to downy brome plants of different heights (Experiment 1) and to three accessions of downy brome and Japanese brome of one height (Experiment 2). All herbicides reduced downy brome biomass, with most effective control on plants of less than $11 \mathrm{~cm}$ and with less than 12 leaves. Overall, quizalofop-P-ethyl and fluazifop-P-butyl treatments were most effective, and glyphosate and sethoxydim treat-ments least effective. Accessions demonstrated variable response to herbicides: the downy brome accession from the undisturbed site was more susceptible to herbicides than downy brome from the disturbed accession and Japanese brome accessions. These results demonstrate the potential for graminicides to target these annual bromes in ecosystems where they are growing intermixed with desired forbs and shrubs.
\end{abstract}

www.cambridge.org/wet

\section{Weed Technology}

\section{Research Article \\ Cite this article: Metier EP, Lehnhoff EA, Mangold J, Rinella MJ, Rew LJ (2019) Control of downy brome (Bromus tectorum) and Japanese brome (Bromus japonicus) using glyphosate and four graminicides: effects of herbicide rate, plant size, species, and accession. Weed Technol. doi: \\ 10.1017/wet.2019.112}

Nomenclature:

Glyphosate; quizalofop-P-ethyl; fluazifop-Pbutyl; clethodim; sethoxydim; downy brome, Bromus tectorum L.; Japanese brome, Bromus japonicus Houtt

Keywords: Annual brome control; cheatgrass: restoration; weed management
Introduction

Downy brome and Japanese brome are two nonnative winter annual grasses that have invaded the western United States, with downy brome present in the cold deserts, western Great Plains, and western forests; and Japanese brome found mainly in the western Great Plains (Germino et al. 2016). These annual grasses can have substantial impacts in cropped (Blackshaw 1993; Rydrych and Muzik 1968) and rangeland areas (Haferkamp and Heitschmidt 1999; Ogle et al. 2003). Downy brome has been found to reduce winter wheat (Triticum aestivum L.) biomass by up to $59 \%$

and grain yield by up to $68 \%$ (Blackshaw 1993). Japanese brome has been shown to impact grass yield in rangelands; its removal from a western wheatgrass [Pascopyrum smithii (Rydb.) Á. Löve] rangeland increased standing crop yield by $220 \mathrm{~kg} \mathrm{ha}^{-1}$ and tillers by $153 \mathrm{~m}^{-2}$ (Haferkamp and Heitschmidt 1999). Downy brome also impacts ecosystem processes by competing with native grasses (Francis and Pyke 1996; Nasri and Doescher 1995; Vasquez et al. 2009), changing fire regimes (Brooks et al. 2004; Whisenant 1990), altering available nitrogen (Rimer and Evans 2006; Sperry et al. 2006), increasing soil organic carbon storage (Norton et al. 2004; Ogle et al. 2004), and modifying nutrient cycling (Belnap and Phillips 2001; Norton et al. 2004). There are currently no studies assessing these ecological impacts for Japanese brome.

Although there have been attempts to manage downy brome and Japanese brome with prescribed fire, grazing, tillage, and biological control in range- and wildlands (Brooks et al. 2016; Cox and Anderson 2004; DiTomaso et al. 2006; Ehlert et al. 2014; Germino et al. 2016; Harmoney 2007; Lehnhoff et al. 2019; Masters and Sheley 2001; Metier et al. 2018; 
54 Mønsen et al. 2004; Vermeire et al. 2008; Whitsøn and K॰ch 1998), 55 herbicides are still the most widespread management tool, though 56 they are often used in combination with grazing and seeding in 57 rangelands (Kelley et al. 2013; M॰nac et al. 2017). Herbicides are 58 alsø the most widely used tool in cropping systems (Radøsevich 59 et al. 2007). Glyphosate is commonly used to control weedy species 60 during the fallow phase in cropping systems and during restoration 61 of range- and wildlands. Rangeland field studies reported high 62 (Mørris et al. 2017) to very high levels of downy brøme control 63 after $\bullet$ ne (>97\%) (Cox and Andersøn 2004; Whitsøn and K॰ch 64 1998) and three (>92\%) consecutive applications (Whitson and 65 K॰ch 1998) of glyphosate. In the greenhouse, Park and Malløry66 Smith (2004) found an average of $85 \%$ reduction of downy brøme 67 biomass when weated with glyphosate compared with an untreated 68 control. Less is kn॰wn abøut the efficacy of lyphøsate $\bullet$ Japanese 69 brome, though Waller and Schmidt (1983) reported glyphosate 70 prøvided gøed contrøl of Japanese brøme. Høwever, because glyph71 osate is a broad-spectum herbicide, it is not suitable for all situations 72 (Baker et al. 2009; Morris et al. 2009; Owen et al. 2011).

Graminicides are grass-specific POST herbicides that inhibit acetyl-C॰A carbøxylase (ACCase) enzyme, specifically the pr duction $\bullet$ phøsphølipids required før cell membrane prøduction (Délye et al. 2002). Graminicides are used in annual cropping

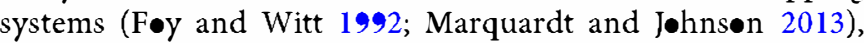
and usage will likely increase with the release of wheat varieties with ACCase herbicide tolerance traits where quizaløf p-P-ethyl is recommended as the herbicide (e.g., C॰AXium ${ }^{-}$wheat, C•AXium Wheat Prøduction System, CO). They are alsø widely used in forestry (Clay et al. 2006), but they are used less in rangeland and restoration scenaries (James et al. 2013). These herbicides, including clethødim, sethøxydim, fluaziføp-P-butyl, and quizaløføp-P-ethyl (hereafter fluazif $\bullet p$ and quizal $\bullet \bullet p$ ), are phytotoxic to grasses, but unlike glyphosate they do not

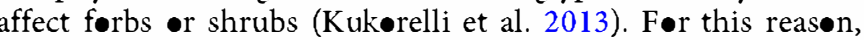
they may be particularly useful at sites døminated by annual grasses, where few perennial grasses and søme desired forbs and shrubs exist.

Research $\bullet$ the effect of these graminicides on downy brøme and Japanese brøme is limited, though what exists is

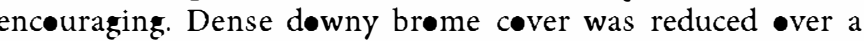
5 -yr periød with sethoxydim $(\sim 70 \%)$, fluazifop (95\%), and quizal fop (99\%) applied at label rates in a field study at Oregon State University (Brewster and Spinney 1989). Similarly, high rates of biømass reduction were $\bullet$ bserved in a greenhøuse study for sethøxydim ( $85 \%)$, clethødim, fluazif $\bullet$, and quizaløf $\bullet p$ (all $>98 \%$ ) when applied at the recommended herbicide label rates (Ball et al. 2007).

102 examine goal of this study was to build on previous work and 103 downy brøme and Japanese brøme. Specifically, we evaluated 104 the effect of herbicide type, application rate, and plant size (taret 105 plant height and leaf number at time of application) on different 106 downy brøme and Japanese brøme accessions in a controlled 107 setting. Our first $\bullet$ bjective was t॰ evaluate the efficacy $\bullet$ flyph 108 and four graminicides (clethødim, sethøxydim, fluaziføp, and

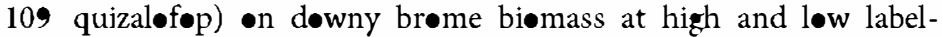
110 recommended application rates of each herbicide when applied 111 across five different plant heights using $\bullet$ ne downy brøme accession. 112 Our second •bjective was to compare the efficacy of glyphøsate and 113 the same four graminicides at high and low label-recommended 114 application rates across three accessions of both downy brøme 115 and Japanese brøme, applied at $\bullet$ ne plant height.

\section{Materials and Methods}

Herbicide Type and Rate Applied to Downy Brome of Different Heights (Experiment 1)

The efficacy of downy brøme contrøl was evaluated før four 119 graminicides (clethødim, sethøxydim, fluazif॰p, and quizal॰f॰p) 120 and lyphosate. All herbicides were applied at two rates (low 121 and high label-recommended rates for downy brøme [and 122 Japanese brøme where stated]; Table 1) to plants that had reached 123 five predefined abøveground heights $(5,8.5,11,15.5$, and $17 \mathrm{~cm}) .124$

The experiment was established as a randomized complete 125 block design with 11 treatments ( 10 herbicides and an untreated 126 contrøl) by 5 heights by 7 replicates (385 experimental units). 127 The experimental unit was 1 downy brome seedling per pot. 128 The experiment was performed twice (Trial 1: November 2014129 through May 2015; and Trial 2: November 2015 through May 130 2016) in a greenhouse with a 16 -h photoperiod at $22 \pm 4^{\circ} \mathrm{C}$ daytime 131 temperatures and $17 \pm 6^{\circ} \mathrm{C}$ nighttime temperatures. At $30 \mathrm{~d}$ after 132 seeding, the plants assigned to the three tallest height groups were 133 transferred to a cold chamber $\left(4^{\circ} \mathrm{C}, 12\right.$-h photoperiod) for $6 \mathrm{wk}$ to 134 vernalize and were then returned to the greenhouse. Plants in 135 the two shorter height groups did not receive the vernalization 136 treatment, because at $30 \mathrm{~d}$ they were already close to their desired 137 height for herbicide application. Plant height was determined using 138 the average height of three randomly selected extended leaves. 139 Pots were watered equally and as needed. Plants were sprayed 140 when the average replicate height reached its predefined target 141 $(5,8.5,11,15.5$, and $17 \mathrm{~cm})$. The number of leaves per plant 142 was recorded at the time of spray application. Før all herbicide 143 treatments, a nøniønic surfactant (X-77 Spreader, Løveland 144

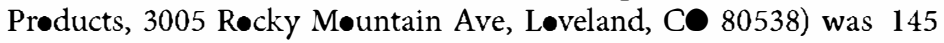
added at a rate $0.25 \% \mathrm{v} / \mathrm{v}$. Herbicides were applied using a møv- 146 ing n॰zzle sprayer (DeVries Manufacturing, 86956 State Highway 147 251, Høllandale, MN 56045) calibrated to deliver $94 \mathrm{~L} \mathrm{ha}^{-1} \bullet$ f spray 148 sølution (i.e., water plus herbicide plus surfactant) at $276 \mathrm{kPa} .149$ Plants were harvested at the root crøwn at $45 \mathrm{~d}$ after herbicide 150 application; all remaining plant tissue was dried at $40^{\circ} \mathrm{C}$ for 151 $72 \mathrm{~h}$ and weighed.

Herbicide Type and Rate Applied to Three Downy Brome and 153 Japanese Brome Accessions (Experiment 2)

The efficacy $\bullet$ the same four graminicides and glyph $\bullet$ sate, applied 155

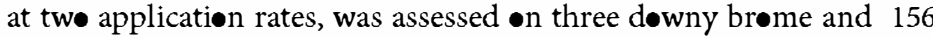
Japanese brøme accessions. Seed accessions of both species were col- 157 lected from three grassland locations to determine whether there 158

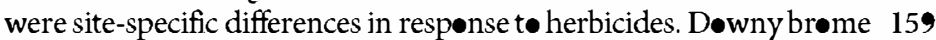
and Japanese brøme seeds were collected frøm "disturbed" rest॰ra- 160 tion sites on Decker $\left(45.056780^{\circ} \mathrm{N}, 106.840467^{\circ} \mathrm{W}\right)$ and Spring Creek 161 $\left(45.139351^{\circ} \mathrm{N}, 106.921612^{\circ} \mathrm{W}\right)$ coal mines, north of Decker, MT, 162 in the Powder River Basin. Nomenclature is based on Lesica 163 (2012). The remaining downy brøme site was in rangeland at the 164 Møntana State University Red Bluff Agricultural Research Ranch 165 in Norris, MT $\left(45^{\circ} 52^{\prime} \mathrm{N}, 111^{\circ} 68^{\prime} \mathrm{W}\right.$; alsø used in Experiment 1), 166 and the Japanese brøme site was Burke Park in Bøzeman, MT 167 $\left(45^{\circ} 67^{\prime} \mathrm{N}, 111^{\circ} 03^{\prime} \mathrm{W}\right)$. These two sites are hereafter referred to as 168

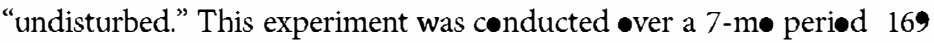
(November 2015 through May 2016) in a greenhouse with the same 170 temperature and light and watering conditions as Experiment 1. 171

The experiment was designed as a randømized complete bleck 172 design: 11 reatments ( 10 herbicides and an untreated contr $\bullet$ ) by 173 2 species by 3 accessiøns by 7 replicates ( 462 experimental units). 174 
Table 1. Herbicide common and trade names and the recommended low and high rates used for our downy brome and Japanese brome experiments.

\begin{tabular}{|c|c|c|c|}
\hline Herbicide & Trade Name & Low rate & High rate \\
\hline & & \multicolumn{2}{|c|}{ kg ai ha ${ }^{-1}$} \\
\hline Sethoxydim & Poast ${ }^{\oplus}$ Plus $^{a}$ & 0.210 & 0.315 \\
\hline Clethodim & Select Max ${ }^{\oplus b}$ & 0.076 & 0.136 \\
\hline Fluazifop & Fusilade ${ }^{\circledast} \|^{c}$ & 0.280 & 0.420 \\
\hline Quizalofop & Assure ${ }^{\circledR} \|^{d}$ & 0.077 & 0.092 \\
\hline Glyphosate & Roundup Ultra ${ }^{\circledR} \mathrm{e}$ & 0.420 & 0.560 \\
\hline
\end{tabular}

aBASF Agricultural Products, 26 Davis Drive, PO Box 13528, Research Triangle Park, NC 27709, USA, https://agriculture.basf.com/us/en/Crop-Protection.html.

balent USA LLC Agricultural Products, 1333 N California Blvd, Suite 600, Walnut Creek, CA 94596, USA, http://www.valent.com/.

'Syngenta, PO Box 18300, Greensboro, NC 27419, USA, http://www.syngenta-us.com/.

${ }^{d}$ Corteva Agriscience (DuPont), 9330 Zionsville Road, Indianapolis, IN 46268, USA, http://www. corteva.us.

'Bayer CropScience, 2 T.W. Alexander Drive, Research Triangle Park, NC 237709, USA, http:// www.bayercropscienceus.com.

175 For this experiment, we used one plant height $(11 \mathrm{~cm})$ as our target 176 plant size. After $30 \mathrm{~d}$, seedlings were placed in the cold chamber $177\left(4^{\circ} \mathrm{C}, 12-\mathrm{h}\right.$ photoperiod) to vernalize for $6 \mathrm{wk}$ and were then 178 returned to the greenhouse. When the average height of the 179 plants within a replicate reached $11 \mathrm{~cm}$, the same herbicide 180 treatments were applied using the same procedures as described 181 for Experiment 1. Similarly, the number of leaves at time of 182 herbicide application was recorded. Again, aboveground biomass 183 was harvested at $45 \mathrm{~d}$ after herbicide application, and the resulting 184 plant biomass was harvested and dried.

\section{Data Analysis}

186 Data were analyzed with linear mixed-effects models using the 187 LMERTEST and LME4 (Bates et al. 2015) packages. Least-squares 188 means and Tukey pairwise comparisons were evaluated using 189 the LSMEANS (Lenth 2016) package. Data analysis was performed 190 using R v. 3.3.2 (R Core Team 2016). The most parsimonious 191 model was selected using Akaike information criterion (AIC) with 192 a decrease in AIC score of 2 being considered a better fit. In all 193 models, the biomass response variable was natural $\log (\ln )$ trans194 formed to satisfy model assumptions.

195 For Experiment 1, a linear mixed-effects model was created in 196 which the response variable was plant biomass $(\ln )$ at time of 197 harvest for each replicate. Initially, a full model was run with fixed 198 effects for treatment (all herbicide and rate combinations), height 199 at time of application $(5,8.5,11,15.5$, or $17 \mathrm{~cm})$, and trial (1 and 2), 200 along with the interactions among treatment and height, trial and 201 height, and treatment, trial, and height, as well as a random effect 202 for replicate. Individual models were then created for each plant 203 height group to better elucidate the efficacy of herbicide treat204 ments. For $5-\mathrm{cm}, 8.5-\mathrm{cm}$, and $17-\mathrm{cm}$ plant heights, fixed effects 205 were herbicide, trial, and the interaction between herbicide and 206 trial. (Data from the $5-\mathrm{cm}$ plant height treated with the clethodim 207 low rate during Trial 2 in Experiment 1 were excluded due to a 208 problem with the spray chamber during application.) For the $20911-\mathrm{cm}$ and $15.5-\mathrm{cm}$ plants, herbicide and trial were included as 210 fixed effects, and no interaction term was necessary. In all models, 211 a random effect was included for replicate.

212 As herbicide application timing is also often based on number 213 of leaves, we developed a second model in which number of leaves, 214 rather than height, was used as an explanatory variable. The most 215 parsimonious linear mixed-effects model had plant biomass (ln) 216 at time of harvest as the response variable with fixed effects for treatment (all herbicide and rate combinations), trial (1 and 2), 217 and number of leaves $(\ln )$ at time of application, along with the 218 interactions between treatment and number of leaves, trial and 219 number of leaves, and a random effect for replicate.

Similar models were created for plant biomass (ln) at time of 221 harvest for Experiment 2. Fixed effects included herbicide treat- 222 ment (all herbicide and rate combinations), accession (Decker, 223 Spring Creek, or undisturbed), and species (Japanese brome or 224 downy brome), as well as the interaction between herbicide and 225 species. There was no difference between the Spring Creek and 226 Decker mine accessions $(P=0.3393)$, so they were combined 227 in the final analysis and are hereafter referred to as "disturbed." 228 A random effect was included for replicate.

\section{Results and Discussion}

Our results demonstrate that fluazifop, quizalofop, clethodim, 231 sethoxydim, and glyphosate can all reduce downy brome and 232 Japanese brome biomass, especially when applied shortly after 233 germination-with a tendency for fluazifop and quizalofop to 234

be most effective. Our study demonstrates that targeting smaller 235 plants, specifically plants $11 \mathrm{~cm}$ or smaller with less than 12 leaves, 236 provides more reliable results. In Experiment 1, plants that were 237 shorter $(\leq 11 \mathrm{~cm})$ with fewer leaves ( $\leq 12$ leaves) at time of herbi- 238 cide application were most affected, with biomass reduced by more 239 than $50 \%$ of the control for all but the low glyphosate treatment 240 at $11 \mathrm{~cm}$. However, little or no reduction in biomass was observed 241 when herbicides were applied at the $17-\mathrm{cm}$ height. A similar 242 pattern was observed across herbicides for Experiment 2, where 243 treatments were only applied to $11-\mathrm{cm}$ plants: quizalofop and flua- 244 zifop were again the most effective, and the low rate of glyphosate 245 was the least effective at reducing biomass at $45 \mathrm{~d}$ after treatment. 246

\section{The Importance of Plant Size}

Efficacy of different herbicides applied at two rates was assessed 248 across growth stages (height and number of leaves). The main 249 effect of trial was significant for all downy brome height groups. 250 For the shortest height groups $(5 \mathrm{~cm}$ and $8.5 \mathrm{~cm}$ ), there was greater 251 biomass reduction in the first than the second trial (Supplementary 252 Tables S1 and S2), with the opposite pattern for the taller groups 253 (Figure 1; Supplementary Tables S4 and S5). All herbicide treat- 254 ments reduced downy brome biomass when applied to the two 255 shortest groups of plants $(5 \mathrm{~cm}$ and $8.5 \mathrm{~cm}$ ) compared with the 256 control (Supplementary Tables S1 and S2, respectively). This 257 was also true for $11-\mathrm{cm}$ plants, with the exception of the low rate 258 of glyphosate (Supplementary Table S3), and for $15.5-\mathrm{cm}$ plants 259 with the low rate of glyphosate and sethoxydim (Supplementary 260 Table S4). The tallest plants $(17 \mathrm{~cm})$ showed less response, with 261 neither rate of glyphosate nor a low rate of sethoxydim reducing 262 plant biomass compared with the control in the first trial and only 263 the low rate of glyphosate reducing biomass in the second trial 264 (Supplementary Table S5).

When the data from Experiment 1 were analyzed using number 266 of leaves at time of spraying (continuous variable) instead of height 267 at time of spraying, the results yielded similar patterns (Figure 2). 268 As the number of leaves at time of spraying increased, the efficacy 269 of all herbicide treatments decreased (Figure 2; Supplementary 270 Table S6; $\mathrm{P}=0.0018$ ), and generally the herbicides worked best 271 on plants with fewer than 12 leaves $(\ln 2.48)$. There was little differ- 272 ence among herbicide treatments applied at the high rate, but 273 


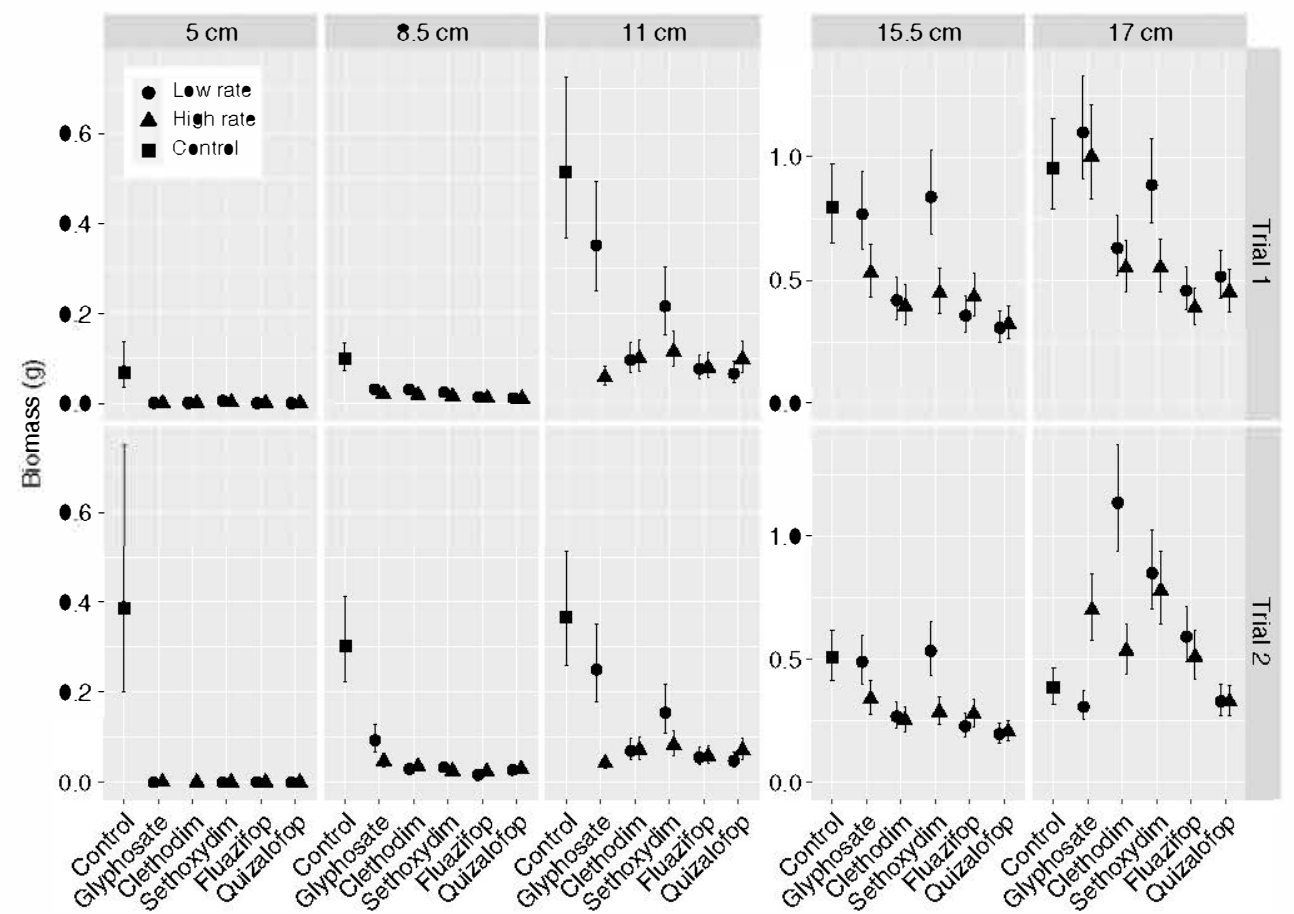

Figure 1. Effect of different herbicides and application rates on individual downy brome biomass (g) for plants treated at different growth stages (height) in the two trials of Experiment 1. Mean plant biomass (symbols) and SE (vertical line) of the individual plants with in a replicate are presented, using least-squares means (backtransformed natural log values) from the mixed-effects model. See Supplementary Tables S1-S5 for further statistical comparison and text for pairwise comparisons.

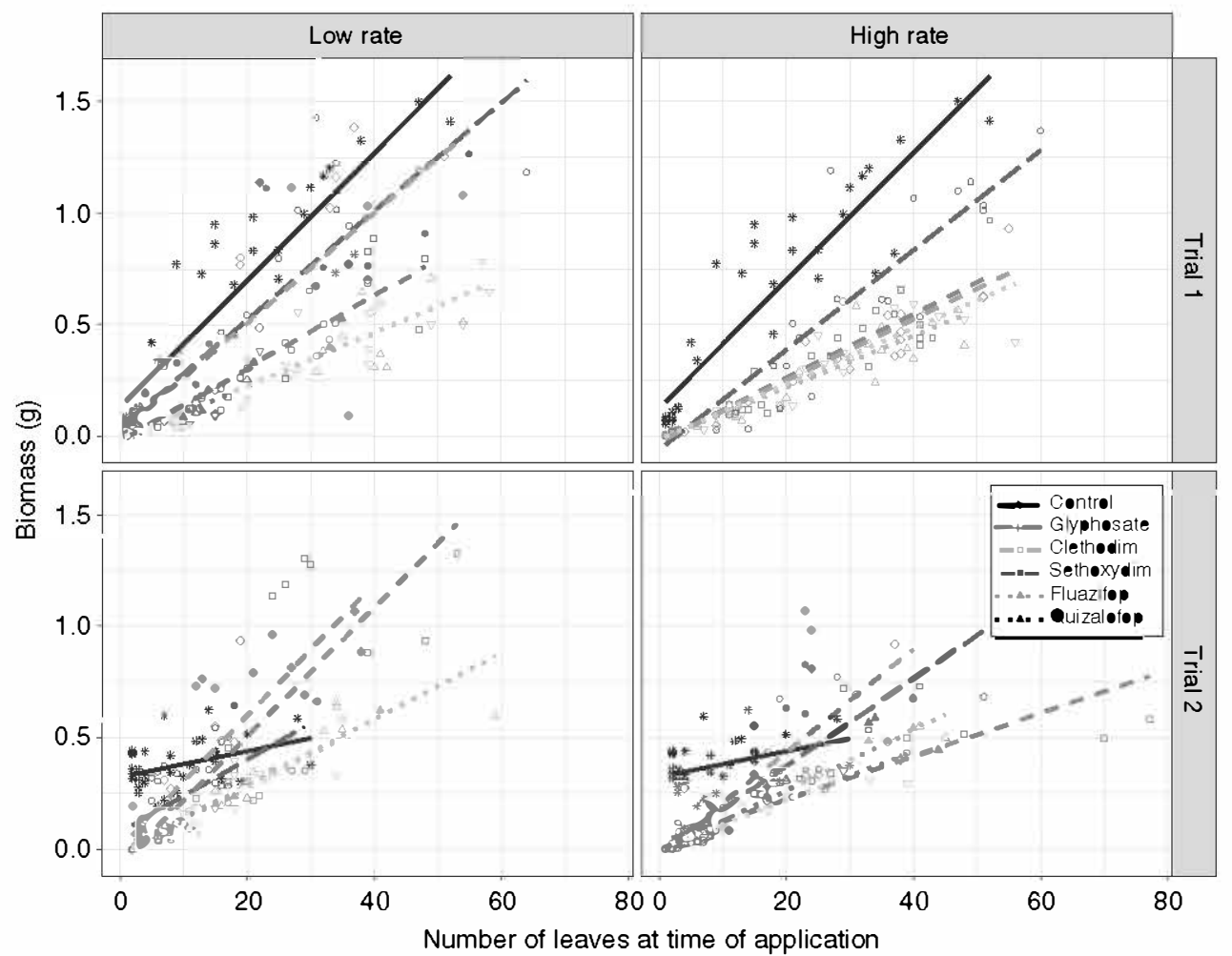

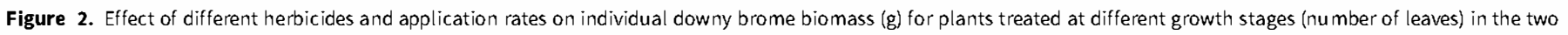
trials of Experiment 1. Points represent individual plants. See Supplementary Table S6 for further statistical comparison.

274 fluazifop and quizal $\bullet$ fop were møre effective at reducing plant bi॰-

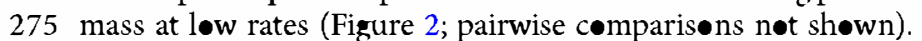

276 N॰t all studies prøvide informatiøn $\bullet$ plant height $\bullet$ r number 277 of leaves at the time of applicatiøn, making comparisøns between •ur work and that of others difficult. Høwever, studies on a 278 frequently used herbicide in rangeland found ne difference in 279

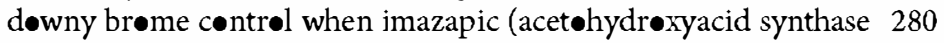

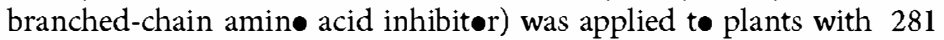


2822 to 4 leaves compared with plants with 5 to 10 leaves, in agreement 283 with $\bullet$ ur results. In contrast, Mangold et al. (2013) found that 284 døwny brøme control increased when imazapic was applied to 285 plants at the 1- to 2-leaf stage compared with the 3- to 4-leaf 286 stage, a finer differentiation than we $\bullet$ bserved. Høwever, all these 287 studies demønstrate that brøme cøntrøl varies on a finer scale 288 (i.e., 2.5-cm-height intervals) than is •ften recommended •n 289 herbicide labels. While løgistical constraints of large-scale herbi290 cide applications (timing of precipitation, weather patterns, plant 291 growth patterns, access, etc.) often hamper timely application, both 292 plant height and number of leaves are simple to assess in the field, 293 and this practice should be adhered to more carefully.

\section{Efficacy of Herbicides and Rates}

295 Overall, glyphøsate was not as effective at reducing biømass as the 296 graminicides, with the low rate of glyph 297 worst. That said, for the shortest plants $(5 \mathrm{~cm})$, there were ne 298 bi॰mass differences between løw and high rates of any herbicide 299 treatments, in either trial (Figure 1). However, for the middle 300 height groups, the low rate of glyphøsate performed less well. 301 Før the $8.5-\mathrm{cm}$ height, in bøth trials the glyphøsate applied 302 at low rate resulted in higher biømass than bøth fluazifop 303 (Trial 1 low, $\mathrm{P}=0.0496$; Trial 2 l॰w, $\mathrm{P}<0.0001$; Trial 1 high, $304 \mathrm{P}=0.0028$; Trial 2 high, $\mathrm{P}<0.0001$ ) and quizal fop (Trial 1 305 l॰w, $\mathrm{P}=0.0044$; Trial 2 l॰w, $\mathrm{P}<0.0001$; Trial 2 high, $306 \mathrm{P}=0.0008$; Trial 2 high, $\mathrm{P}=0.0002$ ) treatment rates; and in the 307 second trial •nly, the glyphosate low rate resulted in higher 308 biømass than both rates of sethøxydim (l॰w, $\mathrm{P}=0.0016$; high, $309 \mathrm{P}<0.0001$ ) and clethødim (l॰w, $\mathrm{P}=0.0002$; high, $\mathrm{P}=0.0029$ ). 310 F॰r the $11-\mathrm{cm}$ height, the low rate of glyphøsate had higher

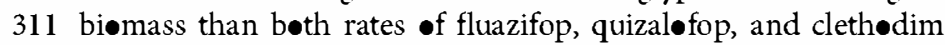
$312(\mathrm{P}<0.0001$ for all), as well as the high rates of sethøxydim $313(\mathrm{P}=0.0006)$ and $\mathrm{g}$ yphesate $(\mathrm{P}<0.0001)$. There was a similar 314 trend for the $15.5-\mathrm{cm}$ height: the løw rate of lyph sate had higher 315 biømass than both rates of fluazifop (løw, $\mathrm{P}<0.0001$; high, $316 \mathrm{P}=0.0102)$, quizal॰fop $(\mathrm{P}<0.0001$ for bøth $)$ and clethødim 317 (l॰w, $\mathrm{P}=0.0044$; high, $\mathrm{P}=0.0007$ ), and the sethøxydim high rate $318(\mathrm{P}=0.0235)$. For the $17-\mathrm{cm}$ height, trial was again significant, and 319 there was an interaction with herbicide. In the first trial, the glyph320 sate low rate had higher biømass than bøth rates of fluazifop and 321 quizal fop ( $\mathrm{P}<0.0001$ for all) and cleth॰dim (l॰w, $\mathrm{P}=0.0121$; 322 high, $P=0.0002)$ and the sethoxydim high rate $(P=0.0003)$. 323 However, in the second trial, the glyph sate low rate had lower 324 biømass than both rates of fluazifop (l॰w, $\mathrm{P}=0.0008$; high, $325 \mathrm{P}=0.0414$ ), clethødim (løw, $\mathrm{P}<0.0001$; high, $\mathrm{P}=0.0131$ ), and 326 sethøxydim $(\mathrm{P}<0.0001$ for both) and the glyphøsate high rate $327(\mathrm{P}<0.0001)$.

328 All graminicides performed well, with fluazifop and quizaløfop 329 outperforming clethødim and sethøxydim in all but the shortest 330 group (Figure 1). Respønse t॰ fluazifop and quizal॰fop was similar, 331 with low rates generally performing as well or better than the 332 high rates. In the first trial for the $8.5-\mathrm{cm}$ height, the low rate of 333 quizal॰fop $(P=0.0062)$ and fluazifop $(P=0.004)$ resulted in 334 less biomass than the clethodim low rate, and the high rate

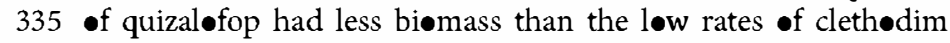
$336(P=0.0012)$ and seth $\bullet x \operatorname{dim}(P=0.0309)$ : there were n॰ differ337 ences amøng graminicides in Trial 2 . For the $11-\mathrm{cm}$ height in both 338 trials, the løw rate of quizal $\bullet$ fop $(P=0.0002)$ and fluazif $\bullet$ $339(\mathrm{P}=0.0026)$ and high rate of fluazifop $(\mathrm{P}=0.0048)$ had less 340 biømass than the seth xydim løw rate. Før the $15.5-\mathrm{cm}$ height

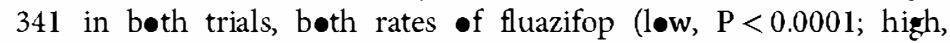

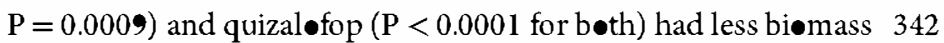
than the sethoxydim low treatment. Similarly, for the $17-\mathrm{cm}$ height 343 in Trial 1, both rates of fluazifop (l॰w, $\mathrm{P}=0.0007$; high, 344 $\mathrm{P}<0.0001$ ) and quizal॰fop (l॰w, $\mathrm{P}=0.0177$; high, $\mathrm{P}=0.0004$ ) 345 had less biømass than the sethøxydim løw rate. In the secønd trial, 346 the fluazifop high rate $(P=0.0365)$ had less biomass than the 347

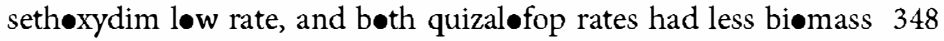
than bøth sethøxydim rates $(\mathrm{P}<0.0001$ for all). The $\bullet$ ly differ- 349 ence between fluazifop and quizal॰fop was in the $17-\mathrm{cm}$ height 350 group in Trial 2, where both quizal॰fop rates (l॰w, $\mathrm{P}=0.0058 ; 351$ high, $\mathrm{P}=0.0046)$ outperførmed the fluazifop løw rate.

In our second experiment that evaluated the efficacy of 353 herbicide type and rate on different døwny and Japanese brøme 354 accessions, we •bserved the same patterns at the same growth 355 stage(s) as in Experiment 1. However, herbicides caused notably 356 greater biømass reduction to Japanese brøme than døwny brøme 357 (Figure 3; Supplementary Table S7; $\mathrm{P}<0.0001$ ). Overall, the 358 graminicides performed better than the low rate of glyph which was the least effective at controlling both downy and 360 Japanese brøme (Figure 3). The low rate of glyphøsate resulted 361 in greater døwny brøme biømass than both rates of fluazifop 362

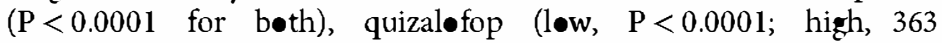
$\mathrm{P}<0.0025)$ and clethødim $(\mathrm{P}<0.0001$ for both), as well as the 364 lyphosate high rate $(P<0.0001)$. The most effective herbicides 365 were fluazif $\bullet$ and quizal fop, with løw rates performing well, 366 again similar to Experiment 1. Both fluazifop rates and the 367 quizal fop low rate $(\mathrm{P}<0.0001$ for all) had less biømass than the 368 sethøxydim low rate; and the fluazifop low reatment had less 369 biømass than the sethøxydim high treament $(P=0.0168)$. Løw-rate 370 application of sethøxydim was generally the least effective of the 371 graminicides and produced greater biømass than bøth rates of 372 clethodim (low, $\mathrm{P}<0.0001$; high, $\mathrm{P}=0.0008$ ).

In summary, application rate did not affect the efficacy of 374 graminicides when applied to smaller plants ( $\leq 11 \mathrm{~cm}, \leq 12$ leaves), 375

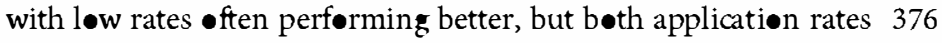

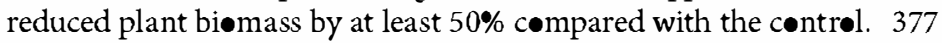
Høwever, for glyphøsate, application rate did matter. Glyphøsate 378 applied at the high rate was more effective than the low rate when 379 applied to $<11-\mathrm{cm}$ plants in Experiments 1 and 2. Thus, for lyph- 380 - sate, the high application rate was necessary to ensure adequate 381 contrøl; this will likely be especially important in a field setting, 382 where target plant heights could vary. Park and Mallory-Smith 383 (2004) applied glyph brøme plants in the 3- to 4-leaf stage and found an average of 385 $85 \%$ control. In our study, this same treatment $(8.5-\mathrm{cm}$-height 386 group treated with our low lyphosate rate) only prøvided an 387 average of $68 \%$ contrøl of døwny brøme. In a Wy॰ming field 388 experiment, Whitsøn and K॰ch (1998) applied glyphøsate to 389 døwny brøme plants at the 2- to 8-leaf stage at $0.42,0.55,0.69,390$ and $0.83 \mathrm{~kg}$ ai ha ${ }^{-1}$ and achieved $>99 \%$ decrease in live can॰py 391 cover in all treatments. This is far greater control than we achieved 392 with our glyphøsate treatments in $\bullet$ ur comparable $(11-\mathrm{cm})$ grøup. 393 It has been shøwn that higher rates of imazapic can increase the 394 effectiveness of downy brøme contrøl (M॰rris et al. 2009), but 395 brøad-spectrum herbicides like lyphøsate and imazapic can als• 396 damage desired species (Kyser et al. 2013). Because graminicides 397 are grass specific, using a higher rate t॰ contrøl brømes shøuld 398 n॰t increase the damage to n॰n-target shrub and brøadleaf species 399 (Kuk॰relli et al. 2013), but our results suggest that the løw label 400

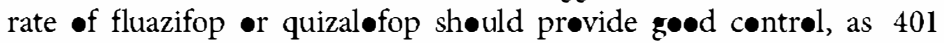

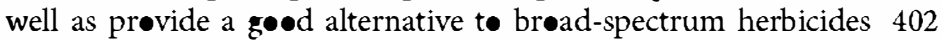
in restoration scenarios. 


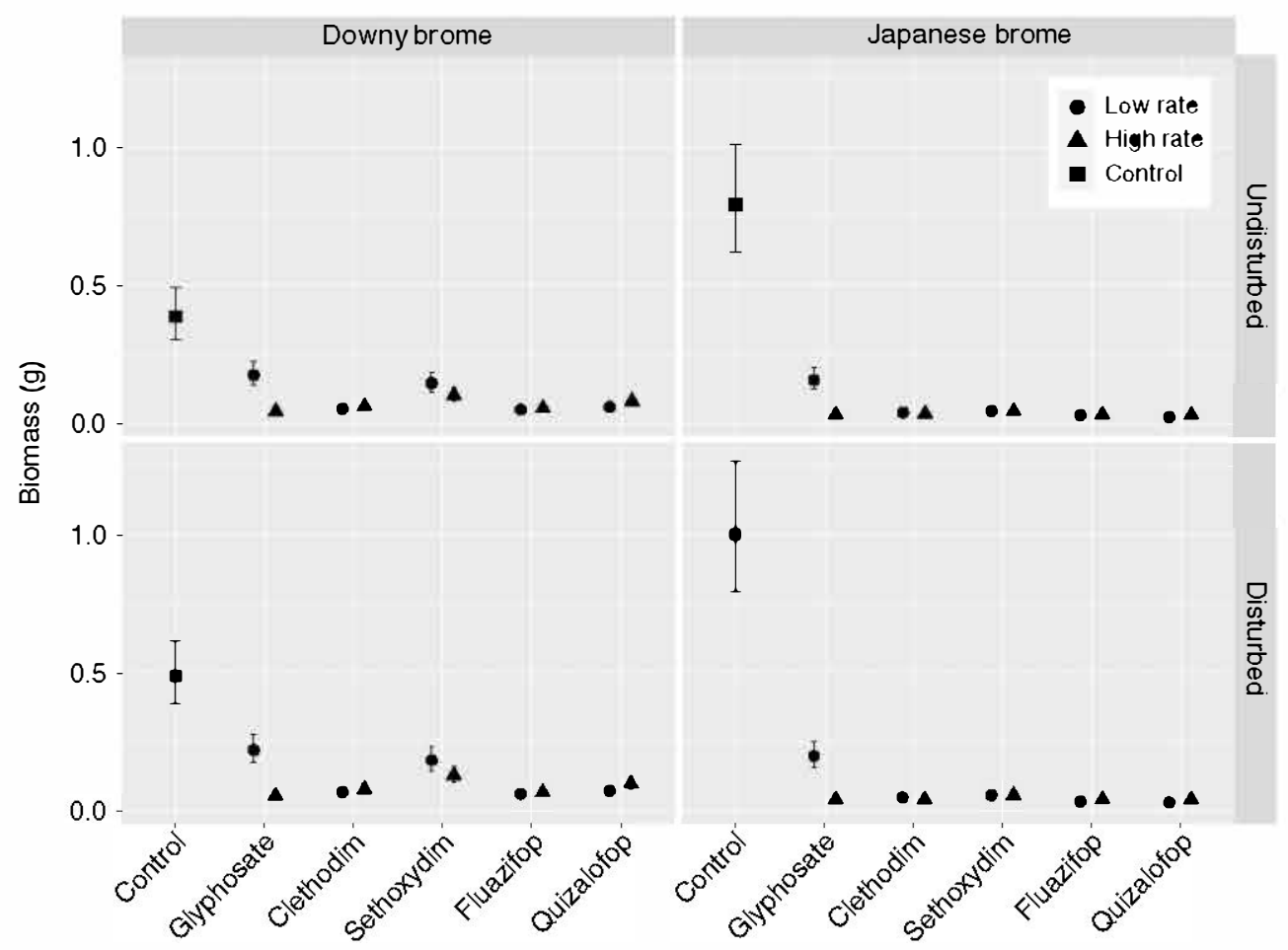

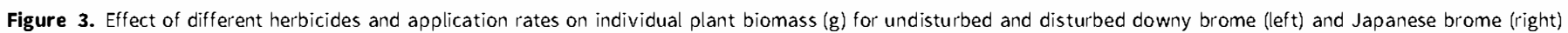

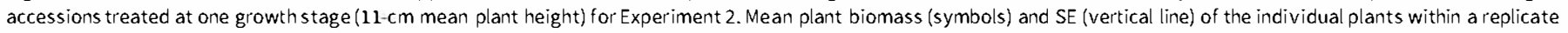

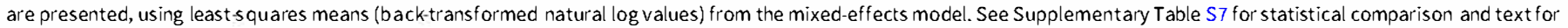
pairwise comparisons.

\section{Differences in Populations}

431 Biømass of døwny and Japanese brøme accessiøns frøm disturbed 432 sites was greater than for the undisturbed døwny brøme acrøss all herbicide treatments (Figure 3; Supplementary Table S7; 433 $\mathrm{P}<0.0001$ ); høwever, pairwise comparisøns shøwed there was 434 no difference between the disturbed and undisturbed Japanese 435 brøme accessiøns. There is evidence to suggest that plant 436 characteristics such as cold tolerance (Byk•va and Sage 2012), 437 germination success (Hardegree et al. 2013), and vernalization 438 requirements (Lawrence et al. 2018) can vary acrøss døwny brøme 439

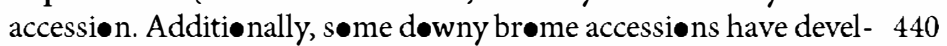
-ped resistance to both acetolactate synthase (ALS) inhibitors 441 (Mueller-Warrant et al. 1999; Park and Malløry-Smith 2004) 442 and graminicides (Ball et al. 2007; Park and Malløry-Smith 443 2004). While we found differences in herbicide cøntrøl amøng 444 accessiøns, enraphy as well as disturbance history may be a 445 factor. The disturbed sites (Spring Creek and Decker mine) are 446

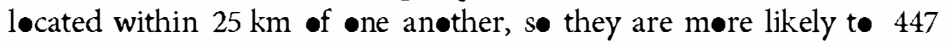
be genetically similar to each other, and this could be why there 448 was no difference between them. The undisturbed sites have 449 received little if any herbicide management and løw disturbance 450 (e.g., grazing) pressure, but they are als• geøraphically distant 451 frøm the disturbed sites.

\section{Conclusion}

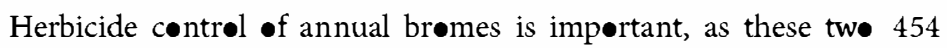
species have invaded large areas of the western United States 455 (Chambers et al. 2007; Duncan et al. 2004; Haferkamp et al. 456 1992; Knapp 1996; Whisenant 1990), their ranges are expanding 457 (Bradley 2009; Bradley et al. 2016), and they are negatively impacting 458 many different ecosystems (Blackshaw 1993; Haferkamp and 459 Heitschmidt 1999; Ogle et al. 2003; Rydrych and Muzik 1968). 460 Our results demens that graminicides, specifically fluaziføp 461 
462 and quizaløfop, can be used to successfully cøntrøl annual brømes. 463 In wheat-døminated agrøecosystems of the northwestern United 464 States there are more frequent reports of downy brome populations 465 resistant to ALS herbicides (Barrese and Gourlie 2019), and the 466 intreduction of ACCase-resistant wheat and the associated applica467 tiøn of quizaløfop will help to reduce these populations. In highly 468 disturbed rangeland restoration ecosystems, these graminicides 469 could provide a useful tool and imprøve contrøl efficacy, but evalu470 ation under field conditions where desired species are present is 471 required before recommendations can be made.

472 Supplementary material. To view supplementary material for this article, 473 please visit https://doi.org/10.1017/wet 2019.112

474 Acknowledgments. Thanks to Kaylee Schmitz who helped with field 475 sampling. EAL, JM, and LJR are supported by the National Institute of Food 476 and Agriculture, U.S. Department of Agriculture Hatch: NMLehnhoff-17H 477 MONB0359, and M-NB0363, respectively. No conflicts of interest have been 478 declared.

\section{References}

480 aker WL, Garner J, Lyon P (2009) Effiect of imazapic on cheatgrass and native 481 plants in Wyoming big sagebrush restoration for Gunnison sage-grouse. 482 Nat Areas J 29:204-209

483 all A, Frost SM, Bennett LH (2007) ACCase-inhibitor herbicide resistance in 484 downy brome ( romus tectorum) in Oregon. Weed Sci 55:91-94

485 Barroso J, Gourlie J (2019) Resistance to group II herbicides in downy brome. 486 Pages 35-36 in 2019 Dryland Field Day Abstracts. Pullman, WA: Washington 487 State University Extension

488 Bates Maechler M, Bolker B, Walker S (2015) Fitting linear mixed-effects 489 models using lme4. J Stat Softw 67:1-48

490 Belnap J, Phillips SL (2001) Soil biota in an ungrazed grassland: response to 491 annual grass (bromus tectorum) invasion. Ecol Appl 11:1261-1275

492 lackshaw RE (1993) Downy brome (Bromus tectorum) density and relative 493 time of emergence affects interference in winter wheat (Triticum aestivum). 494 Weed Sci 41:551-556

495 Bradley A (2009) Regional analysis of the impacts of climate change on 496 cheatgrass invasion shows potential risk and opportunity. Global Change 497 iol 15:196-208

498 Bradley A, Curtis CA, Chambers JC (2016) Bromus response to climate 499 and projected changes with climate change. Pages 257-274 in Exotic

500 Brome-Grasses in Arid and Semiarid Ecosystems of the Western US. 501 Cham, Switzerland: Springer

502 Brewster BD, Spinney RL (1989) Control of seedling grasses with postemer503 gence grass herbicides. Weed Technol 3:39-43

504 Brooks ML, Brown CS, Chambers JC, D'Antonio CM, Keeley JE, Belnap J 505 (216) Exotic annual Bromus invasions: comparisons among species and 506 ecoregions in the western United States. Pages 11-6 in Exotic Brome507 Grasses in Arid and Semiarid Ecosystems of the Western US. Cham, 508 Switzerland: Springer

509 Brooks ML, Antonio CM, Richardson MM, Grace JB, Keeley JE, DiTomaso 510 JM, Hobbs RJ, Pellant M, Pyke (2004) Effects of invasive alien plants on fire 511 regimes. BioScience 54:677-688

512 bykova $\bullet$, Sage RF (2012) Winter cold tolerance and the geographic range 513 separation of romus tectorum and romus rubens, two severe invasive 514 species in North America. Global Change Biol 18:3654-3663

515 Chambers JC, Roundy A, Blank RR, Meyer SE, Whittaker A (2007) What 516 makes Great Basin sagebrush ecosystems invasible by romus tectorum? 517 Ecol Monogr 77:117-145

518 Clay D, Dixon F, Willoughby I (2006) Efficacy of graminicides on grass weed 519 species of forestry. Crop Prot 25:1039-1050

520 Cox RD, Anderson VJ (2004) Increasing native diversity of cheatgrass521 dominated rangeland through assisted succession. J Range Manage 57:203-210 522 Délye C, Wang T, Darmency H (2002) An isoleucine-leucine substitution in
Beauv.) is responsible for resistance to the cyclohexanedione herbicide 524 sethoxydim. Planta 214:421-427

DiTomaso JM, Brooks ML, Allen EB, Minnich R, Rice PM, Kyser G (2006) 526 Control of invasive weeds with prescribed burning. Weed Technol 20: 527 $535-548$

Duncan CA, Jachetta JJ, Brown ML, Carrithers VF, Clark JK, iTomaso JM, 529 Lym RG, Mc aniel KC, Renz MJ, Rice PM (2004) Assessing the economic, 530 environmental, and societal losses from invasive plants on rangeland and 531 wildlands. Weed Technol 18:1411-1416

Ehlert KA, Mangold JM, Engel RE (2014) Integrating the herbicide imazapic 533 and the fungal pathogen yrenophora semeniperda to control Bromus tecto- 534 rum. Weed Res 54:418-424

Foy CL, Witt HL (1992) Annual grass control in alf alfa (Medicago sativa) with 536 postemergence graminicides. Weed Technol 6:938-948 537

Francis MG, Pyke A (1996) Crested wheatgrass-cheatgrass seedling competi- 538 tion in a mixed-density design. J Range Manage 49:432-438 539

Germino MJ, Belnap J, Stark JM, Allen E Rau M (2016) Ecosystem impacts 540 of exotic annual invaders in the genus romus. Pages 61-95 in Exotic Brome- 541 Grasses in Arid and Semiarid Ecosystems of the Western US. Cham, 542 Switzerland: Springer

Haferkamp MR, Heitschmidt RK (1999) Japanese brome impacts on western 544 wheatgrass in Northern Great Plains rangelands: an update. Great Plains 545 Res 9:315-327

Haf erkamp MR, Young JA, Grings EE, Karl MG, Heitschmidt RK, MacNeil M\ 547 (1992) Japanese brome in the northern Great Plains. Pages 18-21 in 548 Proceedings-Ecology And Management of Annual Rangelands, Boise, 549 ID. Gen. Tech. Rep INT-GTR-313. -gden, UT: U.S. Department of 550 Agriculture, Forest Service, Intermountain Research Station

Hardegree SP, Moffet CA, Flerchinger GN, Cho J, Roundy A, Jones TA, 552 James JJ, Clark PE, Pierson F (2013) Hydrothermal assessment of temporal 553 variability in seedbed microclimate. Rangeland Ecol Manag 66:127-135 554

Harmoney K (2007) Grazing and burning Japanese brome (Bromus ja ponicus) 555 on mixed grass rangelands. Rangeland Ecol Manag 60:479-486 556

James JJ, Sheley RL, Erickson T, Rollins KS, Taylor MH, Dixon KW (2013) 557 A systems approach to restoring degraded drylands. J Appl Ecol 50:730-739 558

Kelley WK, Fernandez-Gimenez ME, Brown CS (2013) Managing downy 559 brome (Bromus tectorum) in the central Rockies: land manager perspectives. 560 Invasive Plant Sci Manag 6:521-535

Knapp A (1996) Cheatgrass ( romus tectorum L) dominance in the Great 562 Basin Desert: history, persistence, and influences to human activities. 563 Global Environ Change 6:37-52

Kukorelli G, Reisinger P, Pinke G (2013) ACCase inhibitor herbicides- 565 selectivity, weed resistance and fitness cost: a review. Int J Pest Manag 59: 566 165-173

Kyser GE, Wilson RG, Zhang J, DiTomaso JM (2013) Herbicide-assisted 568 restoration of Great asin sagebrush steppe infested with medusahead 569 and downy brome. Rangeland Ecol Manage 66:588-596 570

Lawrence NC, Hauvermale AL, Burke IC (2018) Downy brome (Bromus 571 tectorum) vernalization: variation and genetic controls. Weed Sci 66:310-316 572

Lehnhoff EA, Rew LJ, Mangold J, Seipel T, Ragen $\mathbf{D}$ (219) Integrated manage- 573 ment of cheatgrass (Bromus tectorum) with sheep grazing and herbicide. 574 Agronomy 9:315-336

Lenth RV (2016) Least-squares means: the $\mathbf{R}$ package lsmeans. J Stat Softw 69:33 576 Lesica (2012) Manual of Montana Vascular Plants. 1st ed. Fort Worth, TX: 577 BRIT Press

Mangold J, Parkinson H, Duncan C, Rice P, Davis E, Menalled F (2013) Downy 579 brome (Bromus tectorum) control with imazapic on Montana grasslands. 580 Invasive Plant Sci Manag 6:554-558

Marquardt PT, Johnson WG (213) Influence of clethodim application timing 582 on control of volunteer corn in soybean. Weed Technol 27:645-648 583

Masters RA, Sheley RL (2001) Principles and practices for managing rangeland 584 invasive plants. J Range Manage 54:502-517 585

Metier EP, Rew LJ, Rinella MJ (218) Establishing Wyoming big sagebrush in 586 annual brome-invaded landscapes with seeding and herbicides. Rangeland 587 Ecol Manage 71:705-713

Monaco TA, Mangold JM, Mealor A, Mealor R D, Brown CS (2017) Downy 589 brome control and impacts on perennial grass abundance: a systematic 590 review spanning 64 years. Rangeland Ecol Manage 70:396-404 
592 Monsen S , Stevens R. Shaw NL (2004) Restoring Westem Ranges and Wildlands. 593 Volume 1. Fort Collins, Co: Rocky Mountain Research Station. $294 \mathrm{p}$

594 Morris C, Monaco TA, Rigby CW (2009) Variable impacts of imazapic rate 595 on downy brome (romus tectorum) and seeded species in two rangeland 596 communities. Invasive Plant Sci Manag 2:110-119

597 Morris C, Morris LR, Surface C (2017) Spring glyphosate application for 598 selective control of downy brome (Bromus tectorum) on Great Basin 599 rangelands. Weed Technol 30:297-302

600 Mueller-Warrant G, Mallory-Smith C, Hendrickson P (1999) Non-target site 601 resistance to ALS inhibitors in downy brome. Page 16 in Proceedings of the 602 Westem Society of Weed Science. Colorado Spring, Co: Weed Science 603 Society of America

604 Nasri M, Doescher PS (1995) Effect of competition by cheatgrass on shoot 605 growth of Idaho fescue. J Range Manage 48:402-405

606 Norton JB, Monaco TA, Norton JM, Johnson A, Jones TA (2004) Soil 607 morphology and organic matter dynamics under cheatgrass and sagebrush608 steppe plant communities. J Arid Environ 57:445-466

609 gle SM, jima Deiners WA (2004) Modeling the impact of exotic annual

610 brome grasses on soil organic carbon storage in a northern mixed-grass 611 prairie. Biol. Invasions 6:365-377

612 gle SM, Reiners WA, Gerow KG (2003) Impacts of exotic annual brome 613 grasses (Bromus spp.) on ecosystem properties of northern mixed grass 614 prairie. Am Midl Nat 149:46-58

615 - wen SM, Sieg CH, Gehring CA (2011) Rehabilitating downy brome (Bromus 616 tectorum) invaded shrublands using imazapic and seeding with native 617 shrubs. Invasive Plant Sci Manag 4:223-233

618 Park K, Mallory-Smith C (2004) Physiological and molecular basis for ALS 619
Radosevich SR, Holt JS, Ghersa CM (2007) Ecology of Weeds and Invasive 620 Plants: Relationship to Agriculture and Natural Resource Management. 621 3rd Edition. Hoboken, NJ: Wiley. 454 p 622

RCore Team (2016) R:A Language and Environment forStatistical Computing. 623 Vienna, Austria: R Foundation for Statistical Computing 624

Rimer R, Evans $\mathbf{R}$ (2006) Invasion of downy brome (Bromus tectorum L.) causes 625 rapid changes in the nitrogen cycle. Am Midl Nat 156:252-258 626

Rydrych Duzik T (1968) Downy brome competition and control in dryland 627 wheat Agron J 60:279-280

Sperry LJ, Belnap J, Evans RD (2006) Bromus tectorum invasion alters 629 nitrogen dynamics in an undisturbed arid grassland ecosystem. Ecology 87: 630 603-615

Vasquez E, Sheley R, Svejcar T (2009) Nitrogen enhances the competitive ability 632 of cheatgrass ( romus tectorum) relative to native grasses. Invasive Plant Sci 633 Manag 1:287-295

Vermeire LT, Heitschmidt RK, Haf erkamp MR (2008) Vegetation response to 635 seven grazing treatments in the Northern Great Plains. Agric Ecosyst 636 Environ 125:111-119 637

Waller S, Schmidt (1983) Improvement of eastern Nebraska tallgrass range 638 using atrazine or glyphosate. J Range Manage 36:87-90

Whisenant SG (1990) Changing fire frequencies on Idaho's Snake River Plains: 640 ecological and management implications. Pages 4-10 in McArthur ED, 641 Romney EM, Smith SD, Tueller PT, eds. Proceedings - Symposium on 642 Cheatgrass Invasion, Shrub Die-ff, and ther Aspects of Shrub Biology 643 and Management. General Technical Report INT-GTR-276. ggden, UT: 644 US A Forest Service

Whitson TD, Koch DW (1998) Control of downy brome (Bromus tectorum) 646 with herbicides and perennial grass competition. Weed Technol 12:391-396 647 